Journal of Contemporary Educational Research

Research Article

\title{
The Difference Between Chinese Myth and Western Myth and its Reflections on Culture
}

Wenhao Shi

Foreign languages institute of Xihua University, Chengdu 610039, Sichuan Province, China

\begin{abstract}
Myth is a kind of story from ancient times. Both Chinese and western cultures have myths. And they are quite different in the shaping of the Gods. Although there are also many similarities between them, but we can find out the reason why two different cultures can develop on the same land, and the key is the differences. The western myths have two big parts called Greek mythology and Nordic mythology, these two myths have some differences, too. So, I want to explore the cultural differences reflected in different myths.
\end{abstract}

Key words: Mythology; Cultural differences; Chinese and Western

Publication date: October, 2020

Publication online: 31 October, 2020

*Corresponding author: Wenhao Shi,675587138@, qq.com

\section{Introduction}

Myth is a kind of imagination and literary product. It comes from ancient people's reflections about the changes of environment. These changes might be the climate change, natural disaster and social transformation. Why different people from the same land can invent such different myths, from the different cultures we can find the answer.

\section{Compared with Greek mythology, Nordic mythology's birth is later}

Firstly, compared with Greek mythology, Nordic mythology's birth is later. It has an obviously reason is that the Nordic mythology is a mythological system peculiar to Scandinavia. Scandinavia has Norway and Sweden and it is surrounded by Iceland, Denmark and Finland. The word "Scandinavian" is derived from the Teutonic "skadino", meaning "darkness", plus the suffix -via representing the territory, the full name means "dark place". We all know it is a land with high latitudes and long winter nights. In this harsh environment, the late birth of Nordic mythology is entirely reasonable. Different from the Greek mythology full of Romanticism, what Nordic mythology brings us is the ruthlessness of reality and the cruelty of fate. People who lived in the frosty forests couldn't feel the warmth from the Gods, so they created a world that is not just about love and beauty.

As Mao Dun said in Nordic Mythology ABC, "Nordic mythology is solemn and tragic ${ }^{[1]}$." Gods in Nordic mythology are just like the normal human beings with power who in charge of the land of God. They also have to face the death and the foe, Giants. But on the contrary, Gods in Greek mythology are all supreme and unmatched. Greek mythology came from ancient Greek's creation. Ancient Greece is a period of glorious golden civilization. Many famous city-states were born in this time. Because the flourishing and splendid culture, Greek mythology has a vivid interpretation of what is powerful and beautiful. Ancient Greek had wisdom and power, so they created Gods with these characteristics along with immortal lives. This kind of Gods and myth promoted the development of western countries. The Renaissance is one of the greatest proofs.

One of the basic characteristics of ancient Greek culture is its humanistic spirit ${ }^{[2]}$. And the humanistic spirit made people's creations pay more attention to people's truth, goodness and beauty, the expansion is Greek mythology. The Renaissance wanted to reproduce 
the glory of ancient Greece. So many litterateurs' works are full of the charm of Greek mythology, because their spirits are all people-oriented. For example, the themes of Shakespeare's dramas refer to the themes of love, redemption and revenge in ancient Greek mythology. Greek mythology has many heroism stories, so are Shakespeare's works. But the most important spirit from Shakespeare's works that makes me think it is a kind of inheritance of Greek mythology is freedom, optimistic and hope $\mathrm{e}^{[3]}$. "What's past is prologue." This kind of relief fully embodies people in the Renaissance pursued the light of ancient Greece. And this is how Greek mythology affects the western culture.

Just as Greek mythology nourishes Western Europeans, Nordic mythology cultivates a group of Northern Europeans with fierce hearts. They worship the heroic God of perseverance and bravery, and they also want to be the Dragon Knight to breaking the cold and darkness of northern Europe with fire. Nordic mythology actually engraves this kind of spirit on northern Europeans' minds, whether it's the Viking era or today, Nordic people have always shown their fortitude. Even though they are not so frantic than before, but they also occupy a place in the world's business, such as LOGO, IKEA, H\&M and etc. I believe this is inseparable from their serious myth culture. Needless to say, prosperous and colorful art and literature's emerging cannot be separated with Greek mythology's imaginative and romantic stories. Even to this day, Nordic mythology and Greek mythology have still hidden in our lives, Sunday to Friday (Saturday comes from Saturn, the God of agriculture in Roman mythology), Aries to Pisces. Western myth not only affects the Europeans' disposition and life attitude, but also brings delight to people all over the world.

\section{Chinese myths are mainly divided into ancient myths, religious myths, folk myths and literary myths}

Unlike Western mythology has systems contain another world, Chinese myths are mainly divided into ancient myths, religious myths, folk myths and literary myths. It's easy to understand in literal, such as the creation of Pan Gu, the eight immortals crossing the sea, the Goddess Chang's fly to the moon and Journey to the West. I think the origin of ancient myths don't differ from European myth so much, they all come from people's yearning for great persons and heroic leaders in ancient time, such as Yan emperor, Huang emperor and Chi You. These myths are created to explain the history of the Chinese nation and to memorializing heroic deeds. But when we talk about religious myths, there is a big different between Chinese mythology and Western mythology. Generally speaking, European mythology is antagonistic to religion, but Chinese religious myths come from the three religions and the nine schools of thought, thus it can be seen that the cultures of Confucianism, Buddhism and Taoism have so many influences on Chinese mythology. Folk myth is my favorite type of Chinese myths, because it is more real and closer to people's lives. They exactly have many unrealistic imaginations, but they also have more true stories with a little exaggeration. I can vividly feel the characters' emotional change rather than just get to know some supreme symbols with no sentiment. And this is one another special characteristic in Chinese mythology, that is even in myths, there is a world with strict feudal hierarchy. Zeus and Odin both have the greatest power, but the Jade Emperor may not have the strongest body. Besides, the thought of family and country constitute to be a world is deeply rooted among the Chinese people, so Chinese myths pay more attention to overall situation. There are always many heroes who attract people's attention, for instance, the Monkey King who made havoc in heaven, but in the end, he still embarked on the road of learning from the West for the sake of the overall situation. Therefore, we can easily find the most important difference that is Chinese culture pays attention to harmony and ethical supremacy ${ }^{[4]}$; Western culture derived from ancient Greek civilization emphasizes individuality and explores wisdom.

Another significant difference is that Chinese mythology is scattered but Western mythology is systematic. On one hand, I strongly believe that ancient Chinese people sometimes consider those Gods as their true ancestors or real divinities instead of their imaginations. It's often said that "Deities are witnessing people all the time", this is inseparable from the culture that Chinese people often revere gods to cultivate themselves ${ }^{[5]}$. On the other hand, Mao Dun also talked about the reason why there are only sporadic parts of Chinese mythology in his book A Preliminary Study of Chinese Mythology. One is the historicization of mythology, and the other is that there was no great event in the society to stimulate the whole nation's soul to induce the emergence of "God's spokes-poet". The second reason is regrettable, but the first reason is worth 
discussing.

The historicization of mythology means the myths and the histories are blended together, as a result that we read the myths along with Chinese histories ${ }^{[6]}$. "It seems to me today that the main body of the original form of Chinese myth is a mixture of myth and history." And in my opinion, it is undeniable that this emergence of phenomenon is developed with China's unique feudal monarchy. The theory that man is an integral part of nature shows that the emperor of China is a kind of God in people's minds. So, Chinese people have more tolerance and acceptability to supernatural being than western people's clear distinction about the man and the god.

\section{Conclusion}

No matter Western mythology or Chinese mythology, they all complement each other's culture ${ }^{[7]}$. "The sea is their backyard, the warship is their boots.", Nordic ancestors who went out to sea to survive and pursue wealth created Gods in the image of fierce pirates, and their mythology is a world of realism. Helen of Troy, the sword of Damocles and Achilles' heel all unfold before our eyes a world of romanticism. Western mythology's excellent people-oriented spirit help Europe become the world's art and culture's paradise. Economy, power and wisdom compose the Western mythology and culture.

Above politics, the cohesion of etiquette and ethics and the national identity created the mix of Chinese mythology and culture. Mythology comes from histories' expansion and cultural reflection; histories and cultures conversely give expression in mythology. Mythology and culture exist side by side and play a part together, so then, two typical myths and cultures with cultural differences between the East and the West are formed.

\section{References}

[1] Mao D. Nordic Mythology ABC [M], Shanghai Bookstore, 1990, preface

[2] Ji L. The humanistic spirit of ancient Greek mythology and its influence on Western culture [J]. Journal of Foreign Languages College of Shandong Normal University, 2001, 48-50

[3] William Shakespeare. The Tempest [M]. China Radio and television press, 2001.7

[4] Yin XY. Cultural differences between China and the West reflected by myths [J]. Journal of Shanxi University of Finance and Economics, 2007, 4, 278-279

[5] Mao D. A Preliminary Study of Chinese Mythology [M]. Jiangsu literature and Art Press, 2009.1

[6] Jin LJ. Rethinking of "historicization" of Chinese Mythology [J], Journal of Baise University, 2009.2, 38-41

[7] Anonymous writer from Iceland, Edda [M], Yilin Translation Publishing House, 2000,1. 